\title{
Adult-Onset Spinal Muscular Atrophy due to Mutations in the VRK1 Gene
}

Angela Sung, MD, Paolo Moretti, MD, and Aziz Shaibani, MD

Neurol Genet 2021;7:e599. doi:10.1212/NXG.0000000000000599
Correspondence

Dr. Shaibani

ataher@aol.com

\section{Abstract}

\section{Objective}

To expand our knowledge of the range of clinical phenotypes associated with vaccinia-related kinase 1 (VRK1) gene mutations.

\section{Methods}

We present clinical and molecular data of 2 individuals with slowly progressive weakness and a clinical syndrome consistent with adult-onset spinal muscular atrophy without pontocerebellar atrophy.

\section{Results}

Genetic testing revealed likely pathogenic variants in the VRK1 gene in both subjects. One individual carried homozygous p.R321C (c.961 C>T), likely pathogenic variants. The other carried compound heterozygous p.V236M (c.706 G>A) and p.R321C (c.961 C>T), likely pathogenic variants. Notably, both patients were of Hispanic descent.

\section{Conclusions}

We report 2 cases with VRK1 mutations presenting as adult-onset spinal muscular atrophy without pontocerebellar hypoplasia and review the current literature of similar cases. Our report expands the clinical spectrum of neurologic disorders associated with VRK1 mutations.

From the Department of Neurology (A. Sung), University of California San Diego; Department of Neurology (P.M.), University of Utah Health Science Center; George E. Wahlen VA Medical Center (P.M.), Salt Lake City, UT; and Nerve and Muscle Center of Texas (A. Shaibani), Houston. 


\section{Glossary}

gnomAD = Genome Aggregation Database; NCS = nerve conduction study; SMA = spinal muscular atrophy; SMN1 = survival motor neuron 1; VRK1 = vaccinia-related kinase $1 ;$ WES $=$ whole-exome sequencing.

The spinal muscular atrophies (SMAs) are a heterogeneous group of disorders characterized by degeneration of the anterior horn cells, resulting in progressive muscle weakness and atrophy. Although the classic form of SMA is caused by mutations in the survival motor neuron 1 (SMN1) gene on chromosome $5 \mathrm{q}$, there are a host of rare non-5q spinal muscular atrophies with varying clinical phenotypes. The vaccinia-related kinase 1 (VRK1) gene is a gene located on chromosome $14 \mathrm{q} 32$ that was fairly recently identified as associated with SMA, particularly a phenotype of SMA with pontocerebellar hypoplasia. The initial case report described infantile onset with clinical features of microcephaly, upper limb ataxia, hyperreflexia, intellectual disability, and motor and sensory neuropathy with cerebellar hypoplasia on imaging. ${ }^{1}$

Since identification, several other cases of VRK1 mutation have been identified with clinical features including congenital/infantile-onset progressive sensorimotor neuropathy with microcephaly, ${ }^{2}$ as well as reports of adult-onset progressive weakness with features consistent with amyotrophic lateral sclerosis ${ }^{3}$ or adult-onset distal hereditary motor neuropathy ${ }^{4}$ without brain abnormalities. The previously reported VRKImutations and associated clinical phenotypes are summarized in the table. Despite these reports of new

Table Summary of Previously Reported VRK1 Mutations

\begin{tabular}{|c|c|c|c|c|c|}
\hline Ref & Sequence variants & Onset & Family history & Phenotype & MRI \\
\hline 1 & Homozygous p.R358X & I & Ashkenazi Jewish & $\begin{array}{l}\text { Delayed motor milestones, ataxia, hyperreflexia, and } \\
\text { intellectual disability }\end{array}$ & $\begin{array}{l}\text { Microcephaly and } \\
\text { cerebellar hypoplasia }\end{array}$ \\
\hline 8 & Homozygous p.R133C & I & Consanguineous family & Intellectual disability & $\begin{array}{l}\text { Cerebellar } \\
\text { hypoplasia }\end{array}$ \\
\hline \multirow[t]{2}{*}{2} & $\begin{array}{l}\text { Heterozygous p.R89Q, } \\
\text { p.V236M }\end{array}$ & I & 2 sisters & $\begin{array}{l}\text { Delayed motor milestones, hypotonia, hyporeflexia, } \\
\text { scoliosis, respiratory compromise, and normal cognition }\end{array}$ & $\begin{array}{l}\text { Microcephaly and } \\
\text { simple gyral pattern }\end{array}$ \\
\hline & Homozygous p.R358X & I & Ashkenazi Jewish & $\begin{array}{l}\text { Delayed motor milestones, hypotonia, tremor, } \\
\text { hypophonia, dysarthria, and scoliosis }\end{array}$ & $\begin{array}{l}\text { Microcephaly, } \\
\text { abnormal gyri, and } \\
\text { vermis }\end{array}$ \\
\hline 3 & $\begin{array}{l}\text { Heterozygous } \\
\text { p.H119R, p.R321C }\end{array}$ & $A$ & Hispanic & $\begin{array}{l}\text { Progressive, distal symmetric weakness/atrophy, pes } \\
\text { cavus, hammer toes, hyperreflexia, and normal cognition }\end{array}$ & Normal \\
\hline \multirow[t]{2}{*}{9} & $\begin{array}{l}\text { Heterozygous } \\
\text { p.H119R, p.R358X }\end{array}$ & C & Ashkenazi Jewish & $\begin{array}{l}\text { Progressive lower limb weakness/atrophy and normal } \\
\text { cognition }\end{array}$ & $\begin{array}{l}\text { Spinal cord and brain } \\
\text { atrophy }\end{array}$ \\
\hline & $\begin{array}{l}\text { Heterozygous } \\
\text { p.G135R, p.L195V }\end{array}$ & C & & $\begin{array}{l}\text { Short stature, microcephaly, distal weakness/atrophy, } \\
\text { hyperreflexia, scoliosis, and respiratory dysfunction }\end{array}$ & Normal \\
\hline 10 & Homozygous p.R358X & $\mathrm{F}$ & Ashkenazi Jewish & Microcephaly, cortical dysplasia, and clubfoot & Microcephaly \\
\hline 11 & Homozygous p.R358X & C & & $\begin{array}{l}\text { Distal weakness in the legs progressing to the arms and } \\
\text { pes cavus }\end{array}$ & Normal \\
\hline 12 & $\begin{array}{l}\text { Homozygous c. } 1159+ \\
\text { 1G>A splice variant }\end{array}$ & C & Family with 5 affected individuals & $\begin{array}{l}\text { Childhood-onset SMA, brisk tendon reflexes, and normal } \\
\text { intellectual ability }\end{array}$ & Normal \\
\hline 13 & $\begin{array}{l}\text { Heterozygous p.T256I, } \\
\text { p.D267G }\end{array}$ & C & & Childhood-onset ALS and intellectual disability & $\begin{array}{l}\text { Pineal cyst, } \\
\text { otherwise normal }\end{array}$ \\
\hline 14 & Homozygous p.W375X & C & 2 siblings, Han Chinese & Symmetric, distal weakness/atrophy & Normal \\
\hline 4 & Homozygous p.R387H & $A$ & $\begin{array}{l}2 \text { cases from unrelated } \\
\text { consanguineous Moroccan Jewish } \\
\text { families }\end{array}$ & $\begin{array}{l}\text { Weakness, calf atrophy, absent Achilles reflexes, and } \\
\text { normal sensation }\end{array}$ & Normal \\
\hline 15 & $\begin{array}{l}\text { Heterozygous p.R89X, } \\
\text { p.G257S } \\
\text { Heterozygous } \\
\text { c.T71014C (intron 8), } \\
\text { p.R241C }\end{array}$ & C & 2 unrelated cases & Weakness and pyramidal signs & Normal \\
\hline
\end{tabular}

Abbreviations: $\mathrm{A}$ = adult; C = childhood; F = fetal; I = infancy; Ref = reference (see References section for corresponding reference). 


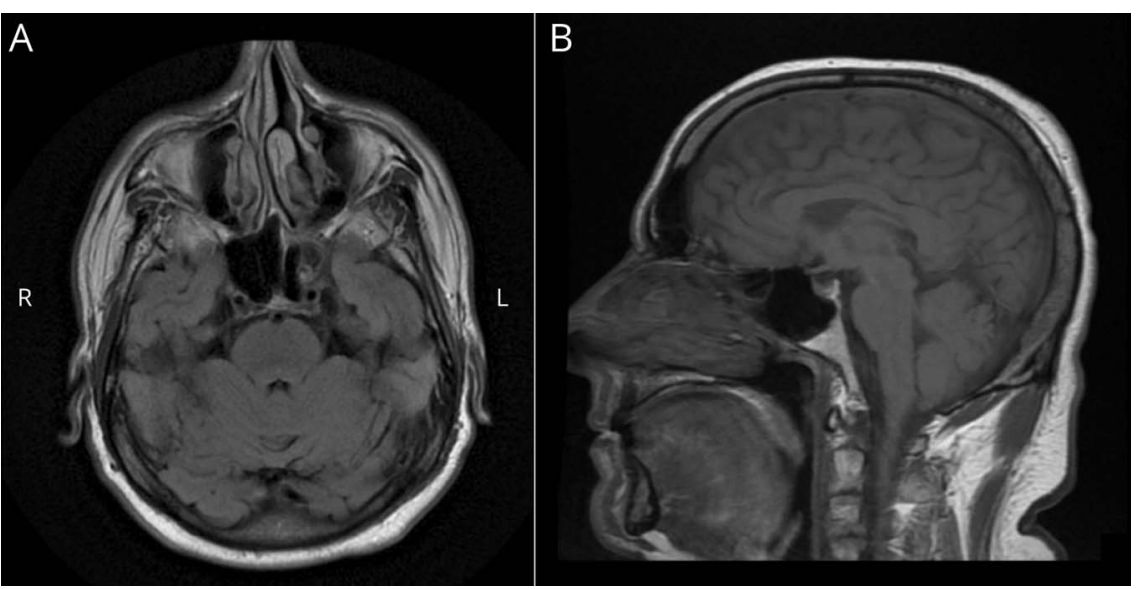

(A) Axial T2 fluid-attenuated inversion recovery through the pons and cerebellum and (B) sagittal T1 through the brainstem and cerebellar vermis without any evidence of pontocerebellar atrophy. phenotypes, the Online Mendelian Inheritance in Man database still lists pontocerebellar hypoplasia type $1 \mathrm{~A}$ as the single phenotype associated with VRK1 pathogenic variants. Here, we report 2 cases of VRK1 mutations resulting in an adultonset SMA-like phenotype without pontocerebellar hypoplasia.

\section{Methods}

Clinical evaluation of patients was performed at the Nerve and Muscle Center of Texas. Verbal consent for publication was obtained from the patients. Diagnostic workup included brain MRI, EMG, and nerve conduction studies (NCSs), and whole-exome sequencing (WES). NextGen whole-exome sequencing was performed on an Illumina system with 100 base pairs or greater paired-end reads. Depth of coverage ranged between $121 \times$ maximum and $10 \times$ minimum and $98.7 \%$ of the exome was surveyed. Hundred percent of the $V R K 1$ coding region was covered at a minimum of $10 \mathrm{x}$.

\section{Standard Protocol Approvals, Registrations, and Patient Consents}

Verbal consent for publication was obtained from the patients.

\section{Data Availability}

Anonymized data will be shared by request from any qualified investigator.

\section{Case 1}

A 51-year-old Hispanic man presented for evaluation of worsening weakness over 20 years. He reported weakness mainly in the lower extremities, resulting in difficulty with climbing stairs and rising from a deep chair. In addition, he experienced muscle cramps and low back pain but no myalgias, dysarthria, dysphagia, or double vision. On examination, he had bilateral calf atrophy and $4+/ 5$ strength in hip flexion and plantar flexion and $3+/ 5$ strength in dorsiflexion as rated

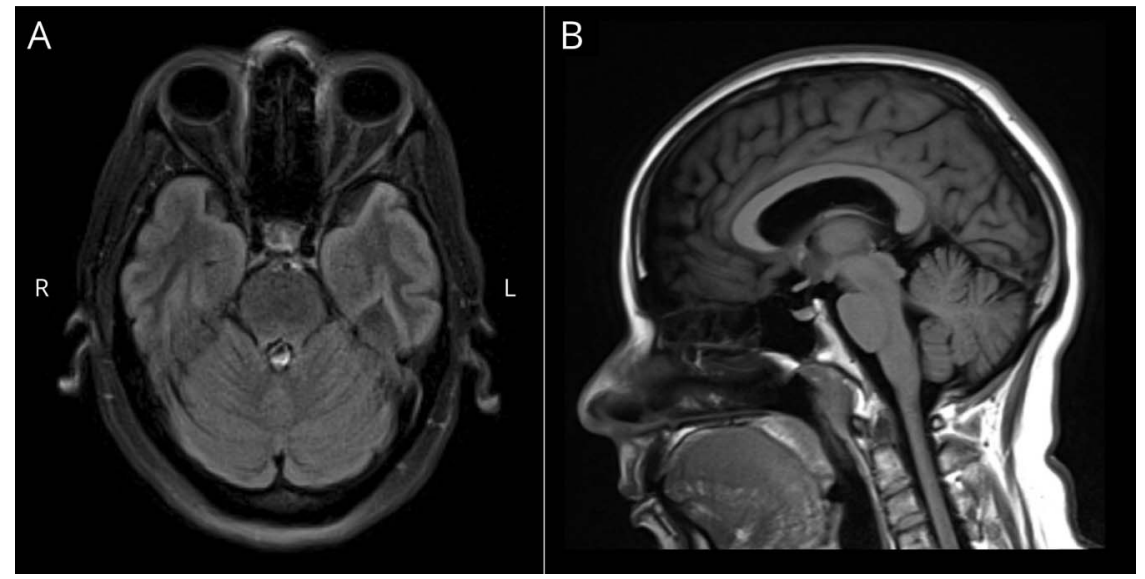


Figure 3 Serine/Threonine-Protein Kinase VRK1 Conservation Across Evolution

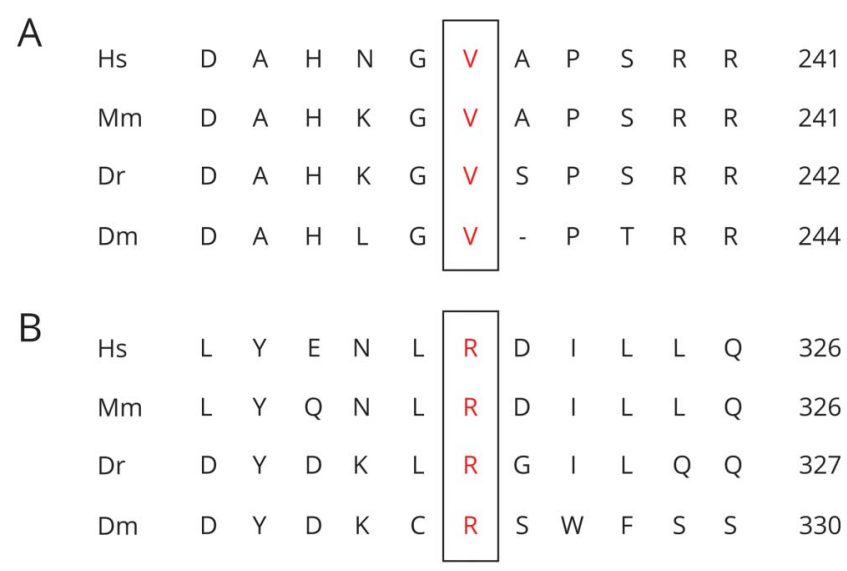

Multiple protein alignments highlight the high degree of evolutionary conservation of valine at position 236 (A) and arginine at position 321 (B) of the human amino acid sequence. The numbers on the right side of each sequence correspond to the last amino acid depicted. $\mathrm{Dm}=$ Drosophila melanogaster; $\mathrm{Dr}=$ Danio rerio; $\mathrm{Hs}=$ Homo sapiens; $\mathrm{Mm}=$ Mus musculus.

on the Modified Research Council grading scale. He had normal strength in the arms. Reflexes were normal except for absent ankle reflexes. The rest of the neurologic examination, including mental status, speech, sensation, and coordination, was unremarkable.

EMG/NCSs showed normal sensory nerve conductions, lowamplitude motor responses, and neurogenic motor units predominantly in the lower extremities. This was consistent with a picture of motor neuron disease. Creatine kinase was elevated at 3,400 IU/L. Brain MRI was normal (figure 1). Genetic testing for SMN1 gene deletion was not detected. WES identified a homozygous, likely pathogenic variant in the VRK1 gene (c.C961T, p.R321C).

\section{Case 2}

A 55-year-old Hispanic woman presented for evaluation of progressive lower extremity weakness. She had noticed symptoms since age 16 years when she had difficulty marching in the band, and 2-3 years later, she began walking with a limp. Gradually, she developed bilateral foot drop and weakness of hand grips. She reported twitching in the thigh muscles and poor balance. She denied sensory symptoms, dysphagia, dysarthria, visual symptoms, and muscle cramps. On examination, she was noted to have distal atrophy in the arms and legs without fasciculations. Strength was $1 / 5$ in dorsiflexion/plantar flexion, 2/ 5 in hip flexion, and $4 / 5$ in the deltoids and biceps. She had absent ankle reflexes, but otherwise normal reflexes. The rest of the neurologic examination was unremarkable.

EMG/NCSs showed normal sensory nerve conductions, lowamplitude motor responses, and widespread active and chronic denervation in the upper and lower extremities proximally and distally. Brain MRI was normal (figure 2). WES identified compound heterozygous (c.G706A, p.V236M and c.C961T, p.R321C) pathogenic variants in the VRK1 gene.

\section{Discussion}

The VRK1 gene encodes a serine kinase that is ubiquitously expressed, including in the fetal and adult brain and cerebellum. The serine/threonine-protein kinase VRK1 has been shown to phosphorylate a number of substrates, including $\mathrm{p} 53$, in an autoregulatory loop that is important for the development and maintenance of the nervous system. ${ }^{5,6} \mathrm{Al}$ though the survival motor neuron protein is also known to interact with $\mathrm{p} 53$, whether disease mechanisms are shared between SMN1- and VRK1-related disorders is currently not known.

We identified 2 individuals with clinical features of lower motor neuron disease consistent with adult-onset spinal muscular atrophy. Compared with previous SMA cases reported in the literature, these 2 cases demonstrate later onset of disease with milder clinical symptoms. Unlike most of the previously reported cases, there was no evidence of pontocerebellar hypoplasia or cognitive symptoms.

Of all current VRK1 variants identified in individuals with neurologic disease, only p.R358X is currently reported in ClinVar as pathogenic. Increasing our understanding of VRKI variants in neurologic disease in different populations is an important goal. Both of our subjects were found to carry the R321C sequence variant. In the first case, the variant was found in the homozygous state, and in the second subject, it was in a compound heterozygous state with V236M. VRK1 $\mathrm{R} 321 \mathrm{C}$ was previously reported as a compound heterozygous variant with $\mathrm{H} 119 \mathrm{R}$ in an individual with adult-onset amyotrophic lateral sclerosis. ${ }^{3}$ VKR1 V236M was previously reported as a compound heterozygous variant with R89Q in 2 siblings with rapidly progressive sensorimotor polyneuropathy and microcephaly. ${ }^{2}$

VRK1 residues 321 and 236 are evolutionarily conserved from fruit flies to humans, and the variants identified are predicted to be deleterious (figure 3). Of interest, both variants are present at very low frequency in control individuals of European, African, and Asian descent in the Genome Aggregation Database (gnomAD). ${ }^{7}$ In contrast, allele frequency of R321C and V236M is higher in the Latino population $(0.095 \%$ and $0.015 \%$, respectively). It is important that no homozygous individuals for either of these 2 variants are found in gnomAD, suggesting that despite the heterozygote frequency in the Latino population, these variants are likely pathogenic. As a comparison, R358X, an established VRK1 pathogenic variant, 
is found at higher frequency in individuals of Ashkenazi Jewish descent in gnomAD $(0.14 \%)$ compared with other populations and is also not observed in the homozygous state in this database.

Our 2 cases, combined with the previous reports by Nguyen and Greenbaum, suggest that VRK1 variants may present with adult-onset motor neuron disease without pontocerebellar atrophy. In addition, our data suggest a role in pathogenicity for both VRK1 R321C and V236M. Identification of R321C in the homozygous state in an affected individual (case 1) and its absence in homozygosity in control populations, despite the presence of this variant in heterozygosity in a large percentage of normal individuals, argues for a pathogenic role of R321C. Moreover, our data show that disease caused by R321C and V236 may be more common in Latinos compared with other populations.

Spinal muscular atrophy related to mutations in the VRK1 gene is a relatively recently identified association. We reported 2 cases with VRK1 mutations presenting as adultonset spinal muscular atrophy without pontocerebellar hypoplasia. Genetic testing in patients like ours is important to expand understanding of the clinical spectrum of this disorder.

\section{Study Funding}

No targeted funding reported.

\section{Disclosure}

The authors report no disclosures relevant to the manuscript. Go to Neurology.org/NG for full disclosures.

\section{Publication History}

Received by Neurology: Genetics June 7, 2020. Accepted in final form March 23, 2021.

\section{Appendix Authors}

\begin{tabular}{lll}
\hline Name & Location & Contribution \\
\hline $\begin{array}{l}\text { Angela } \\
\text { Sung, MD }\end{array}$ & $\begin{array}{l}\text { University of California, } \\
\text { San Diego }\end{array}$ & $\begin{array}{l}\text { Reviewed the literature, drafted } \\
\text { the initial manuscript, and made } \\
\text { multiple revisions }\end{array}$ \\
\hline $\begin{array}{l}\text { Paolo } \\
\text { Moretti, } \\
\text { MD }\end{array}$ & $\begin{array}{l}\text { University of Utah Health } \\
\text { City }\end{array}$ & $\begin{array}{l}\text { Interpreted data, investigated } \\
\text { sequence variants in genetic } \\
\text { databases, and made multiple } \\
\text { revisions }\end{array}$ \\
\hline $\begin{array}{l}\text { Aziz } \\
\text { Shaibani, } \\
\text { MD }\end{array}$ & $\begin{array}{l}\text { Nerve and Mexas, Houston } \\
\text { of Tencle Center }\end{array}$ & $\begin{array}{l}\text { Collected clinical data, directed } \\
\text { clinical testing for the patients, and } \\
\text { made multiple revisions }\end{array}$ \\
\hline
\end{tabular}

\section{References}

1. Renbaum P, Kellerman E, Jaron R, et al. Spinal muscular atrophy with pontocerebellar hypoplasia is caused by a mutation in the VRK1 gene. Am J Hum Genet. 2009;85(2):281-289.

2. Gonzaga-Cauregui C, Lotze T, Jamal L, et al. Mutations in VKR1 associated with complex motor and sensory axonal neuropathy plus microcephaly. JAMA Neurol. 2013;70(12):1491-1498.

3. Nguyen TP, Biliciler S, Wiszneiwski W, Sheikh K. Expanding phenotype of VRK1 mutations in motor neuron disease. J Clin Neuromuscul Dis. 2015;17(2):69-71.

4. Greenbaum L, Barel O, Nikitin V, et al. Identification of a homozygous VRK1 mutation in two patients with adult-onset distal hereditary motor neuropathy. Muscle Nerve. 2020;61(3):395-400.

5. Young PJ, Day PM, Zhou J, Androphy EJ, Morris GE, Lorson CL. A direct interaction between the survival motor neuron protein and p53 and its relationship to spinal muscular atrophy. J Biol Chem. 2002;277(4):2852-2859.

6. Valbuena A, Vega FM, Blanco S, et al. p53 downregulates its activating vaccinia-related kinase 1, forming a new autoregulatory loop. Mol Cell Biol. 2006;26(13):4782-4793.

7. Lek M, Karczewski KJ, Minikel EV, et al. Analysis of protein-coding genetic variation in 60,706 humans. Nature. 2016;536(7616):285-291.

8. Najmabadi H, Hu H, Garshasbi M, et al. Deep sequencing reveals 50 novel genes for recessive cognitive disorders. Nature. 2011;478(7367):57-63.

9. Stoll M, Teoh H, Lee J, et al. Novel motor phenotypes in patients with VRK1 mutations without pontocerebellar hypoplasia. Neurology. 2016;87(1):65-70.

10. Reches A, Hiersch L, Simchoni S, et al. Whole-exome sequencing in fetuses with central nervous system abnormalities. J Perinatol. 2018;38(10):1301-1308.

11. Feng SY, Li LY, Feng SM, Zou ZY. A novel VRK1 mutation associated with recessive distal hereditary motor neuropathy. Ann Clin Transl Neurol. 2018;6(2):401-405.

12. Sedghi M, Moslemi AR, Olive M, et al. Motor neuron diseases caused by a novel VRK1 variant: a genotype/phenotype study. Ann Clin Transl Neurol. 2019;6(11):2197-2204.

13. Yamaura G, Higashiyama Y, Kusama K, et al. Novel VRK1 mutations in a patient with childhood-onset motor neuron disease. Intern Med. 2019;58(18):2715-2719.

14. Li N, Wang L, Sun X, et al. A novel mutation in VRK1 associated with distal spinal muscular atrophy. J Hum Genet. 2019;64(3):215-219.

15. Silva DP, Soeiro E Sá M, Silveira F, et al. VRK1 variants in two Portuguese unrelated patients with childhood-onset motor neuron disease. Amyotroph Lateral Scler Frontotemporal Degener. 2020;3(2):1-5. 


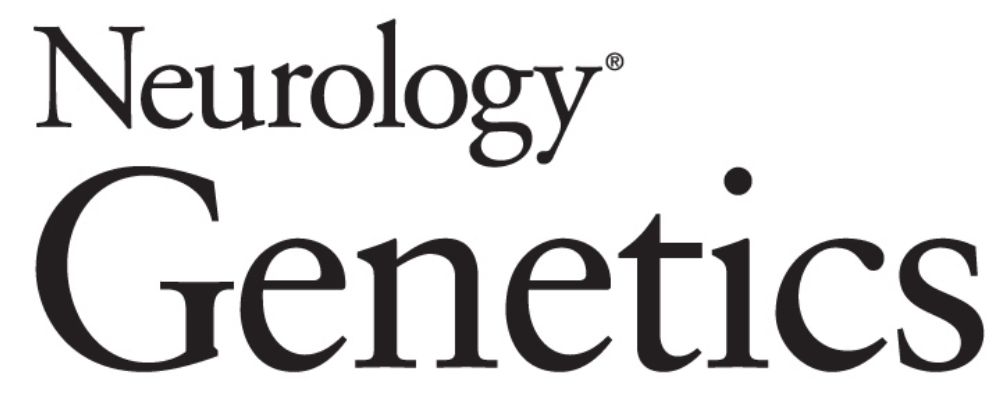

Adult-Onset Spinal Muscular Atrophy due to Mutations in the VRK1 Gene

Angela Sung, Paolo Moretti and Aziz Shaibani

Neurol Genet 2021;7;

DOI 10.1212/NXG.0000000000000599

This information is current as of June 22, 2021

\section{Updated Information \&} Services

References

Permissions \& Licensing

Reprints including high resolution figures, can be found at: http://ng.neurology.org/content/7/4/e599.full.html

This article cites 15 articles, 2 of which you can access for free at: http://ng.neurology.org/content/7/4/e599.full.html\#\#ref-list-1

Information about reproducing this article in parts (figures,tables) or in its entirety can be found online at:

http://ng.neurology.org/misc/about.xhtml\#permissions

Information about ordering reprints can be found online: http://ng.neurology.org/misc/addir.xhtml\#reprintsus

Neurol Genet is an official journal of the American Academy of Neurology. Published since April 2015, it is an open-access, online-only, continuous publication journal. Copyright Copyright $\odot 2021$ The Author(s). Published by Wolters Kluwer Health, Inc. on behalf of the American Academy of Neurology.. All rights reserved. Online ISSN: 2376-7839.

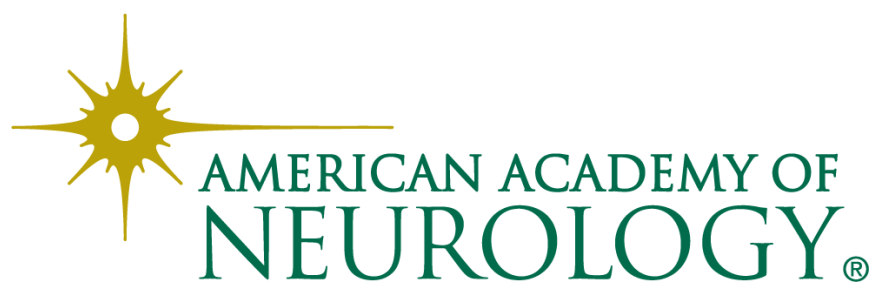

